\title{
Potential cancer targeted therapy: role of microRNAs in breast cancer metastasis via epithelial-mesenchymal transition and cancer stem cell regulation
}

\author{
Pamungkas Bagus Satriyo* \\ Department of Pharmacology and Therapy, Faculty of Medicine, Public Health, and Nursing, \\ Universitas Gadjah Mada, Yogyakarta, Indonesia
}

https://doi.org/10.22146/ijpther.1184

Submitted: 19/01/2021

Accepted : 7/02/2021

Keywords:

breast cancer, microRNA,

EMT,

metastasis,

targeted therapy,

\section{ABSTRACT}

In the advancement of breast cancer treatment, metastatic breast cancer is remaining as an incurable disease. It contributes to almost $90 \%$ of cancer-related death in breast cancer cases. Epithelial to mesenchymal transition (EMT) is a serial change of the epithelial cell to gain the mesenchymal-like phenotype. In cancer, the cells that undergo the EMT lose the adherent junction protein, cell polarity, and gain the invasive phenotype. Recent studies showed that the EMT induces the cancer stem cell-like phenotypes in cancer cells. These cells possess self-renewal ability, and multi-lineage differentiation capacity to generate the new bulk of tumor during cancer distant organ metastasis. Both EMT and cancer stem cells take responsibility in drug-resistant, and relapse cases in breast cancer. In the last decades, a new type of non-coding RNA, microRNA (miR) shows an important role in the normal physiological and pathophysiological condition such as cancer. Recent studies revealed that the EMT is regulated by microRNAs. In this review, we discussed the microRNAs regulation on the EMT process through TGF- $\beta$, and Wnt signaling pathways in breast cancer. Understanding of microRNA regulation in EMT in breast cancer metastasis gives a chance to explore a new therapy approach to improve the prognosis of breast cancer patients. In addition, we also explored several potential approaches targeting microRNA as a new approach of cancer treatment.

\section{ABSTRAK}

Dalam kemajuan pengobatan kanker payudara, metastatis kanker payudara tetap menjadi penyakit yang tidak dapat disembuhkan. Kanker payudara metastatic ini menyumbang hampir 90\% kematian terkait kanker dalam kasus kanker payudara. Epithelial-mesenchymal transition (EMT) adalah perubahan selepitel menjadi sel yang memiliki fenotipe mirip sel mesenkim. Pada kanker, sel yang mengalami EMT kehilangan protein adherent junction, polaritas sel, dan mendapatkan fenotipe yang invasif. Penelitian terbaru menunjukkan bahwa EMT menginduksi fenotipe cancer stem cells. Sel-sel ini memiliki kemampuan pembaruan diri, dan kapasitas diferensiasi multi-lineage untuk membentuk jaringan tumor baru selama metastasis pada kasus kanker. Baik EMT maupun cancer stem cells memiliki peran penting dalam kasus resistensi obat, dan kekambuhan pada kanker payudara. Dalam beberapa decade terakhir, jenis baru non-coding $R N A$, microRNA (miR) memiliki peran penting dalam kondisi fisiologis dan patofisiologis seperti kanker. Penelitian terbaru menunjukkan bahwa EMT diatur oleh microRNA. Dalam ulasan ini, kami membahas regulasi microRNA pada proses EMT melalui jalur pensinyalan TGF- $\beta$, Wnt, dan Twist pada kanker payudara. Pemahaman regulasi microRNA pada EMT dalam kasus metastasis kanker payudara memberikan kesempatan untuk mengeksplorasi pendekatan terapi baru untuk meningkatkan prognosis pasien kanker payudara. Selain itu, kami juga mendeskripsikan beberapa pendekatan potensial yang menargetkan microRNA sebagai pendekatan baru pengobatan kanker. 


\section{INTRODUCTION}

Breast cancer has the highest incidence rate as cancer cases occurred in women. Approximately $25.1 \%$ of women from the worldwide population were diagnosed with breast cancer. In Indonesia, breast cancer is the first ranks cancer-related death in women with an incidence, and mortality rates are $30.5 \%$ and $21.5 \%$ respectively. ${ }^{1}$ Approximately $7 \%$ of breast cancer patients were found with distant metastatic at the diagnosis. ${ }^{2}$ The $20-30 \%$ of early breast cancer patients in diagnosis time will develop distant metastasis with 5-years relative survival rate is only $27 \% .^{3}$ Currently, due to metastatic breast cancer is still considered an incurable disease with a relatively low survival rate. A new approach of breast cancer treatment to improve survival time is needed.

Cellular heterogeneity of cancer tissue is one of the histological hallmarks of cancer. Cellular and molecular heterogeneity of cancer cells in the same tumor leads to a different response to the therapy. Clonal selection of heterogeneous cancer cells or adaptive changes of cancer cells during the treatment induces drugresistant phenotype acquiring. ${ }^{4}$ There is an undifferentiated cancer cell subpopulation called cancer stem cells that possess self-renewal ability, and multilineage differentiation capacity. These cells generate cellular heterogeneity of new bulk of tumor tissue when moving to distant organs during metastasis. ${ }^{5}$ The breast cancer stem cells (BCSCs) express several specific surface markers such as $\mathrm{CD} 44^{\text {high }}, \mathrm{CD} 24^{\text {low/- }}$, and ALDH1 $1^{\text {high }}$. Clinically, co-expression between ALDH1 and $\mathrm{CD} 44^{+} / \mathrm{CD} 24^{-}$are significantly associated with worse prognosis of breast cancer patients. ${ }^{6}$ Interestingly, these breast cancer stem cells can be generated during the EMT-induced by TGF- $\beta$. These cells also exhibit a more radio-resistant phenotype relative to non-breast cancer stem cells. ${ }^{7}$ These findings suggest the tight crosstalk between EMT, and BSCSs promoting metastasis and drug-resistant phenotype in breast cancer.

During epithelial-mesenchymal transition, the proteins that involve in cell-cell junctions of cancer cells are decreased. The cancer cells that undergo EMT also loss the cell polarity, and increase the motility lead to mesenchymal-like properties acquiring. In cancer distant metastasis, there is a subset of cancer cells that circulating to distant organs via the bloodstream called circulating tumor cells (CTCs). These cells could generate the new bulk of tumor when reaching the distant organs. Interestingly, most of the CTCs from metastatic breast cancer possess the EMT and cancer stem cell phenotypes. ${ }^{8}$ In another study, the metastasis breast cancer cells taken from pleural sites were enriched with $\mathrm{CD} 44^{+} / \mathrm{CD} 24$ - cells called breast cancer stem cells. ${ }^{4}$ Taken together, these findings suggest the strong connection between EMT, BSCSs, and breast cancer distant metastasis.

The EMT is tightly regulated by several signaling pathways such as TGF- $\beta$, Sonic Hedgehog, and Wnt signaling pathways. The TGF- $\beta$ signaling pathway is the most known as a key signaling pathway that regulates EMT in cancers. Transforming growth factorbeta is a family of cytokines. Binding of TGF- $\beta$ ligands to its receptors, T $\beta$ RI and T $\beta$ RII activate the SNAIL 1 to suppresses the E-cadherin gene transcription. ${ }^{9}$ In another study, the TGF- $\beta 1$ induces Slug expression leads to inhibiting E-cadherin production. ${ }^{10}$

MicroRNAs are short non-coding RNA (18-24 nucleotides). Recent studies revealed the important role of these non-coding RNA in protein expression regulation. ${ }^{11}$ Intriguingly, almost $60 \%$ of the gene expressions encoding proteins are regulated by microRNAs. These proteins regulate the biological process of the cells including the EMT. The microRNAs regulate EMT through several important signaling pathways such as TGF- $\beta$, and Wnt. Understanding the mechanism of microRNAs as key 
regulators in the EMT process provides the new potential targeted therapy to improve the survival rate of metastatic breast cancer patients.

\section{DISCUSSION}

\section{Epithelial-mesenchymal transition (EMT)}

Epithelial and mesenchymal cells exhibit fundamental differences in protein profiles that are displayed on their cell surface. Epithelial cells highly express E-cadherin, meanwhile, the low expression of E-cadherin is found in the mesenchymal cell surface. The mesenchymal cells also highly express $\mathrm{N}$-cadherin and vimentin. The epithelial cells undergo EMT will lose their apicalbasal polarity, and gain motility as characteristic of mesenchymal cells. ${ }^{12}$ In vitro studies revealed that EMT in breast cancer cells showed decreasing in component surface membrane proteins that play a role in the adherent junction such as E-cadherin and increasing the mesenchymal protein surface markers such as N-cadherin, and vimentin. The cells also gain the invasive ability to penetrate the tissues surrounding the tumor and enter the blood circulation to the distant organs. ${ }^{13}$

Another study showed thatEMT could trigger the emerging of drug-resistant in cancers. In vitro experiments using cell line cholangio carcinoma, the EMTinduced by TGF- $\beta$ will increase ALDH1 expression as well as resistance to the drug 5-fluorouracil. ${ }^{14}$ In breast cancer, the EMT process reduces the responses of breast cancer cells to chemotherapy. ${ }^{15}$ Further, the TGF- $\beta$ treatment induces E-cadherin suppressor expression as well as increases the breast cancer stem cell proportions in the mammary epithelial cells. ${ }^{4}$ These suggest the important role of EMT in breast cancer disease.

\section{Signaling pathways involved in EMT}

Here we described the well-known signaling pathways involved in EMT regulation such as TGF- $\beta$, Wnt, and Twist.
Illustrations of those pathways that led the EMT process were shown in FIGURE $1 \mathrm{a}-\mathrm{c}$.

TGF signaling pathway: One of the signaling pathways that play role in the EMT process is the TGF- $\beta$ signaling pathways. Transformation growth factorbeta is a family of cytokines that acts as a ligand in this signaling pathway. Two types of cell surface receptors, T $\beta$ RI, and T $\beta$ RII are required to transduce the signal from the niche to the cells. The binding of TGF- $\beta$ to both receptor types promote the heterodimer receptor-ligand complex consist of TGF- $\beta$, T $\beta$ RI, and T $\beta$ RII. Active phosphorylated T $\beta$ RII induced by TGF- $\beta$ promotes the auto-phosphorylation of T $\beta R I$. Activation of T $\beta R I$ will trigger the activation of other downstream proteins such as Smad2 and Smad3. The activated Smad2 and Smad3 bind to Smad4 generating Smad2/3/4 complex. Integration between this complex with other transcription factors such as Zeb1, Zeb2/SIP1, Snail, and Slug inhibits the tumor suppressor gene expression, E-cadherin. ${ }^{16}$ Another study revealed that this complex subsequently will bind to the $\mathrm{E}$ box of the E-cadherin gene promoter. The binding attracts histone deacetylase and other repressor proteins causing condensation of the E-cadherin gene. This histone condensation causes the transcription machinery could not access the gene lead to inhibition of the E-cadherin transcription. The loss of E-cadherin not only induces the adherent junctions declining on the cell but can lead to the accumulation of $\beta$-catenin in the cytoplasm. Accumulated $\beta$-catenin promotes its translocation from the cytoplasm to the nucleus. In the nucleus, $\beta$-catenin interacts with transcription factor (TCF) to activate the transcription of transcription factor proteins such as Sox2 and c-Myc. Decreasing of E-cadherin and increasing the transcription factors (Sox2, c-Myc) induced by TGF- $\beta$ signaling pathway activation promotes the mesenchymallike phenotype, and breast stem cell phenotype (CD44 $\left.4^{\text {high }} / \mathrm{CD} 24^{\text {-low }}\right)$ acquiring. ${ }^{4}$ 

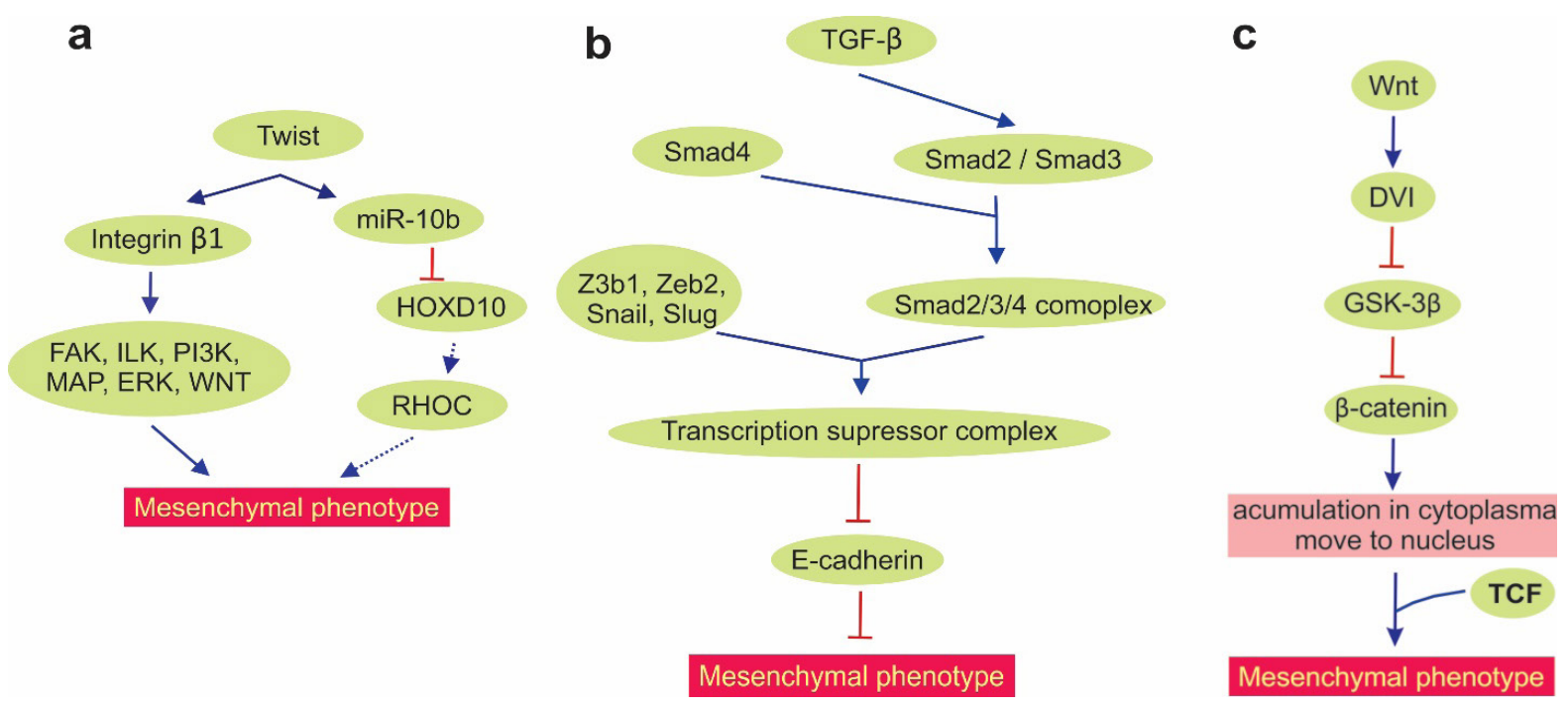

FIGURE 1. Signaling pathways involved in EMT regulation, (a) Twist signaling pathway (b) TGF- $\beta$ signaling pathways, and (c) Wnt signaling pathway.

The Wnt signaling pathway: The binding of Wnt ligands to the cell surface receptors activates downstream proteins of the Wnt signaling pathway in the cytoplasm (disheveled I /DVI). Activated DVI inhibits the phosphorylation of glycogen synthase kinase-3 $\beta$ (GSK-3 $\beta$ )lead to suppression of $\beta$-catenin degradation activity. Accumulation of $\beta$-catenin in the cytoplasm promotes its translocation to the nucleus. In the absence of the Wnt ligand, the GSK-3 $\beta$ present in an activated form in the cytoplasm induce $\beta$-catenin degradation. ${ }^{17}$ Further, the E-cadherin interacts with $\beta$-catenin to form a cadherin-catenin complex which is required in the cell adherent junction structure. Thus inhibits the $\beta$-catenin translocation to the nucleus to activate the downstream target genes of the Wnt signaling pathway. ${ }^{18}$

The disintegration of $\beta$-catenin from the adherent junction complex during Wnt signaling pathway activation promotes the $\beta$-catenin accumulation in the cytoplasm. $\beta$-catenin moves to the nucleus to activate the gene expression by which induce the stemness phenotype of the cells. ${ }^{17}$ Further, the Wnt1 gene silencing using shRNA reduces the expression of stem cell markers such as CD44+, CD24- and migration ability both in vitro and in vivo on breast cancer. ${ }^{19}$

Twist signaling pathway: This signaling pathway was little known compared to the other as TGF- $\beta$ and Wnt. The twist is a transcription factor that has a base loop helix loop. Twist regulate the expression of $\beta 1$ integrin, which is the main regulator in the focal adhesion kinase, integrin-linked kinase, PI3K/AKT, MAPK/ERK, and Wnt signaling which are required during the EMT process. In breast cancer, Twist or $\beta 1$ integrin overexpression could promote the EMT. ${ }^{20}$ Another study found that Twist modulates the E-cadherin, vimentin, miR-10b, AKT2, and IL-8 during the EMT. Although the details of the path downstream twist until the EMT process is not clearly understood. The results showed that Twist 1 and Twist 2 could trigger the EMT process. ${ }^{21}$ Taken together, there is the possibility of inhibiting the EMT via these three signaling pathways suppression as a new approach to decrease the metastasis rate in breast cancer. Even there is crosstalk between TGF- $\beta$ and Wnt signaling in triggering the EMT. ${ }^{4}$

\section{MicroRNA regulation in EMT}

MicroRNAs are single-stranded RNAs with a length of 18-24 nucleotides. 
Although these non-coding RNA exists in a very small amount relative to whole types of RNAs, microRNA possesses an important role in the regulation of gene expression at the post-transcriptional level. These non-coding RNAs were transcribed by RNA polymerases II and III enzymes from its gene.

The transcribed pri-microRNA will undergo several modifications in the nucleoplasm and cytoplasm. The mature small non-coding RNA assembles into RISC to activate this complex called
miRISC (microRNA induced silencing complex). ${ }^{22}$ Active miRISC bind to specific mRNA as a target and promote its degradation. The miRISC could bind to specific mRNA as a target by binding between the seed region sequences of microRNA and the mRNA target sequences. ${ }^{23}$ Some microRNAs and its targets were provided in TABLE 1 . Here we described some microRNAs that have an important role in the EMT of breast cancer cells.

TABLE 1. MicroRNA in the EMT process on breast cancer cells

\begin{tabular}{lllc}
\hline miR & \multicolumn{1}{c}{ miR characteristic } & \multicolumn{1}{c}{ Target } & References \\
\hline miR-1 & Tumor-suppressor miR & Fizzle, TSKN2 & 24,25 \\
miR-203 & Tumor-suppressor miR & MMP2, MMP7, MMP9 & 26,29 \\
miR-205 & Tumor-suppressor miR & Scr-tyrosine kinase & 30,31 \\
miR-10b & OncomiR & HOXD10 & 31,33 \\
miR-29 & OncomiR & N-Myc interactor & 34,36 \\
miR-138 & Tumor-supressormiR & Vimentin, RHBDD1 & 37,38 \\
miR-375 & Tumor-suppressor miR & Metadherin & 39,40 \\
miR-155 & OncomiR & C/EBP $\beta$ protein & 16,41 \\
miR-9 & OncomiR & E-cadherin & 42
\end{tabular}

\section{MicroRNA-1}

The proliferative, migration, and stemness of breast cancer cells are regulated by miR-1. Non-breast cancer stem cells expressed higher miR-1 relative to breast cancer stem cells (CD44 ${ }^{+}$CD24). Ant-miR 1 transfection on the MCF-7 cancer stem cells implanted mice promoted the tumor growth, meanwhile enhancing the microRNA-1 suppressed the tumor growth of MCF7 cancer stem cells implanted mice. ${ }^{24} \mathrm{~A}$ recent study revealed that microRNA-1 overexpression induces apoptosis in breast cancer cells. In addition, the microRNA-1 overexpression also sensitized breast cancer cells to paclitaxel and cisplatin treatment. Consistent with the previous study, the microRNA-1 overexpression suppressed the tumor volume and weight in nude mice. ${ }^{25}$

MicroRNA-1 has a seed region that recognizes the Fizzled and TSKN2
mRNAs. The binding of microRNA-1 to both mRNAs induces mRNA degradation to lead to the suppression of their transcription. Decreasing of both proteins promotes the inhibition of $\beta$-catenin production which is required in Wnt-induced EMT. In the Wnt signaling pathway, $\beta$-catenin binds with TCF to activate target gene expression such as c-Myc. The c-Myc is known as a transcription factor that is required for stemness phenotype regulation. ${ }^{24}$ These findings suggest the microRNA-1 acts as a tumor suppressor microRNA by suppressing the EMT and stemness phenotype of breast cancer cells.

\section{MicroRNA-203}

In prostate, colorectal, and lung cancer, microRNA-203 acts as a tumor suppressor. In breast cancer, decreasing this microRNA is positively associated with distant organ metastasis. Metastatic 
breast cancer cells express microRNA-203 lower than non-metastatic breast cancer cells and normal breast cells. Overexpression of this microRNA suppressed the migration ability of the BT474 breast cancer cell line. ${ }^{26}$

Cell junction stability inhibits migration and metastasis of cancer cells. Cell junction makes cells fixed to a particular space in a particular tissue. Matrix metalloproteinases (MMPs) are enzymes that degrade cell junction proteins allow cell mobility. Upregulating MMP2 and MMP 9 caused by overexpression of Snail protein, enhanced the cell migration in renal cell carcinoma. ${ }^{27}$ In ovarian cancer, repression of MMP7, MMP19, and upregulation of E-cadherin expression significantly repress cell migration and invasion. ${ }^{28}$ MicroRNA-203 is known could inhibit the mRNA expression of MMP2, MMP9, and MMP7 in breast cancer cells. ${ }^{26}$ Another study revealed that microRNA-203 expression level is decreased in breast cancer cells that undergo the EMT process and breast cancer stem cells. This microRNA could enhance the expression of DKK1, a secreted Wnt signaling pathway, and breast cancer stem cell phenotype inhibitor. ${ }^{29}$ These findings suggest the importance of microRNA-203 in EMT, stemness, and metastasis of breast cancer cells.

\section{MicroRNA-205}

This microRNA is categorized as tumor suppressor microRNA. Upregulation of this microRNA suppresses breast cancer aggressiveness and metastasis. Up-regulated microRNA-205 reduces the Scr protein expression level lead to EMT markers, and invasive phenotype inhibition in TNBC cell lines (MDA-MB231 and Hs578t). This Src protein expression levels in invasive breast cancer cell lines, MDA-MB231, and Hs578t are higher than the less invasive cell line, MCF-7. Activation of Src, a proto-oncogene tyrosine-protein kinase induces the EMT process to generating the invasive phenotype in cancer cells. The Src induces the FAK and paxillin activation as the downstream proteins. Both of these proteins promote the expression of the EMT markers Snail, Slug, Twist, and Zeb1 that inhibit E-cadherin gene expression in triple negative breast cancer cells. Overexpression of Src protein induces the invasive mesenchymal phenotype acquiring in triple negative breast cancer cells. ${ }^{30}$ Further, the downregulation of microRNA-205 is associated with more aggressive subtypes, distant metastasis, and worse prognosis of breast cancer patients. Dysregulation of microRNA-205 also affects the proliferation, EMT, metastasis, stemness, and drug-resistant in breast cancer cells. ${ }^{31}$

\section{MicroRNA-10b}

MicroRNA-10b categorize as onco-microRNA. Binding of the Twist transcription factor to microRNA-10b gene activates its gene transcription. Overexpression of microRNA-10b reduces the mRNA and protein level expression of E-cadherin up to $10 \%$ and $20 \%$ respectively. This mechanism resulting in mesenchymal-like phenotype acquisition in cancer cells. ${ }^{32}$ Another study revealed the MicroRNA10b induces EMT via HOXD10 (Homebox D10)/RHOC axis. This microRNA bind to HOXD10 mRNA leads to HOXD10 mRNA degradation. Decreasing of HOXD10 transcription factor promotes the expression of the pro-metastatic gene, RHOC. The RHOC could enhance the metastasis of breast cancer through promoting the EMT. ${ }^{33}$

\section{MicroRNA-29}

Upregulation of microRNA-29 may promote the epithelial cells to turn into mesenchymal-like cells via $\mathrm{N}$-myc interactor regulation. $\mathrm{N}$-myc interactor (NMI) is a protein that possesses as a gatekeeper between the phenotype of epithelial cells and mesenchymal cells. ${ }^{34}$ $\mathrm{N}$-myc interactor suppresses the TGF- $\beta /$ Smad signaling pathway activation 
through activation of Smad7. On the other side, NMI also activates the STAT signaling pathway that suppresses the TGF- $\beta / S$ mad signaling pathway. Taken together, NMI is an important protein to prevent the EMT process. ${ }^{35}$

Cells that have a low NMI exhibit the mesenchymal phenotype. Interestingly, NMI mRNA is the target of microRNA-29. In breast cancer cell lines, transfected cells with miR-29 showed decreasing in NMI expression that leads to generating mesenchymal-like cells. $^{34}$ One of the pathways that regulate the expression of microRNA-29 is Wnt signaling. Uncontrolled activation of Wnt signaling suppresses the GSK-3 $\beta$ activity lead to increasing of microRNA-29 expression level. ${ }^{34}$ These findings suggest the mechanism between the Wnt signaling pathway, microRNA-29, and NMI in EMT regulation. Another study found that microRNA-29 is upregulated in breast cancer stem cells. Overexpression of microRNA-29 induces EMT progression and metastasis via targeting the SUV420H2 in breast cancer cells. ${ }^{36}$

\section{MicroRNA-138}

MicroRNA-138 is downregulated in the breast cancer tissues relative to non-tumor tissues. Clinically, the lymph node metastasis and invasion in breast cancer patients were correlated with the low level of microRNA-138 expression. In vitro study showed the overexpression of this microRNA suppresses the vimentin expression and induces E-cadherin upregulation. This suggests that microRNA-138 inhibits EMT in breast cancer cells. ${ }^{37}$ Another study revealed that microRNA-138 targeting the RHBDD1 mRNA. Thus suppress the cell migration, invasion, and EMT in breast cancer cells. ${ }^{38}$

\section{MicroRNA-375}

Downregulation of microRNA-375 promotes EMT by decreasing the expression ofE-cadherinincancercells.In the MCF-7 cancer cell line, microRNA-375 downregulation increased the oncogene protein, metadherin (MTDH) to trigger the EMT process. $^{39}$ Overexpression MTDH upregulates the fibronectin and promotes beta-catenin accumulation in breast cancer cells. This also reduces the expression of E-cadherin as a surface marker of epithelial cells. Further, several transcription factors such as Snail, and Slug are increased following the MTDH overexpression which promotes the EMT in breast cancer cells. ${ }^{40}$

Based on bioinformatics analysis, the MTDH is the target of miR-375. Interestingly, the long term of tamoxifen treatment reduced the microRNA-375 expression level in breast cancer cells. Eventually, these cells gain mesenchymal phenotype and generate tamoxifen resistance phenotype. This suggests that miR-375 possess important roles in the EMT of cancer cells generating invasiveness and drug-resistant phenotypes. ${ }^{39}$

\section{MicroRNA-155}

MicroRNA-155 plays important role in the EMT pathway through TGF- $\beta$. In physiological conditions, the TGF- $\beta$ inhibits the growth and induces differentiation of epithelial cells through the CCAAT enhancer-binding protein beta $(C / E B P \beta)$ protein as a signaling mediator. This mediator acts as a transcriptional activator of Cdkn2b gene. This gene encodes p15INK4b protein, an inhibitor of the cell cycle. Protein C/EBP $\beta$ also activates gene expression CDH1, Cxadr, Ocln, and Cldn3 gene expressions which are important for cell junction formation in epithelial cell differentiation. Upregulation of microRNA-155 inhibits the expression of the $\mathrm{C} / \mathrm{EBP} \beta$ genes in triple negative breast cancer cells. Thus abrogates the TGF- $\beta$-induced epithelial differentiation and induces the EMT. ${ }^{16}$ This microRNA also involves in drugresistant acquiring in breast cancer cells. ${ }^{41}$

\section{MicroRNA-9}

Upregulated microRNA-9 could promote EMT. The seed region of this 
microRNA recognizes and binds directly to the 3'UTR of E-cadherin mRNA (CHD1) decreasing the E-cadherin level in the cell junctions. Thus induces accumulation of $\beta$-catenin in the cytoplasm. Betacatenin is well-known as an effector protein in the Wnt signaling pathway. The accumulation of $\beta$-catenin in the cytoplasm promotes its translocation from the cytoplasm to the nucleus. In the nucleus, it interacts with the transcription factors (TCF) to increase VEGF expression leading the cancer distant organ metastasis. Myc is one of the main transcription factors that induce increasing in miR-9 level. ${ }^{42}$

\section{Potential approach of microRNA targeted therapy}

Metastasis is associated with poor prognosis and high mortality in breast cancer patients. Even in the less aggressive luminal breast cancer, high mortality occurred in patients with distant organ metastatis. The EMT process holds the key point that promotes metastasis. The epithelialmesenchymal transition generates mesenchymal and cancer stem cell-like phenotypes in breast cancer cells. In the time of spreading to other organs, these cellscould generate new heterogeneous bulk of tumor tissues. ${ }^{5}$ Interestingly, the EMT process also induces resistance phenotypes to the anti-cancer drug such as tamoxifen. ${ }^{39}$ Therefore, targeted therapy to inhibit the EMT process may suppress the distant metastasis and drugresistant phenotype in breast cancer patients.

The EMT process involves complex and numerous signaling pathways. In EMT initiation and progression, cells may use different pathways in the different types of cancers. Understanding the specific signaling pathway that regulates EMT in a particular type of cancer is very important in precision medicine. The appropriateness between therapeutic targets and specific EMT signaling pathways is the key to inhibit EMT. In our review article, the nine microRNAs that play a role in the regulation of EMT through several different pathways in cancer were discussed.

Onco-microRNA and Tumorsuppressor microRNA. Targeted therapy using these microRNAshave great potential because the microRNAs have an important role in EMT regulation through inhibition of some important target proteins. The protein possesses a pivotal role in several signaling pathways on the EMT process such as TGF- $\beta$, Wnt, and Twist. The microRNAs are divided into two types in this article, oncomicroRNA which is related to promote EMT, and tumor-suppressor microRNA that related to EMT inhibition. The role of microRNA in EMT is provided in FIGURE 2. Members of onco-microRNAs are microRNA-10b, microRNA -155, microRNA -9, microRNA -29, whereas tumor-suppressor microRNAs are microRNA -205, microRNA -1, microRNA -375, microRNA -203, and microRNA -138. In the aim to inhibit the EMT in breast cancer cells, the targeted therapy should reduce the onco-microRNAs expression level and/or increase the tumorsuppressor microRNAs expression level. These approaches become visible because the technology-based on microRNAs have been established. The oligonucleotide has been widely studied and has been developed through modifications to improve the efficiency in targeting the dysregulated microRNA in cancer disease. ${ }^{43}$ The onco-microRNA treatment uses a single-stranded oligonucleotide called anti-microRNA, while targeted tumor suppressor microRNA as a treatment approach is performed by using the doublestranded oligonucleotide termed mimicmicroRNA. ${ }^{44}$ 


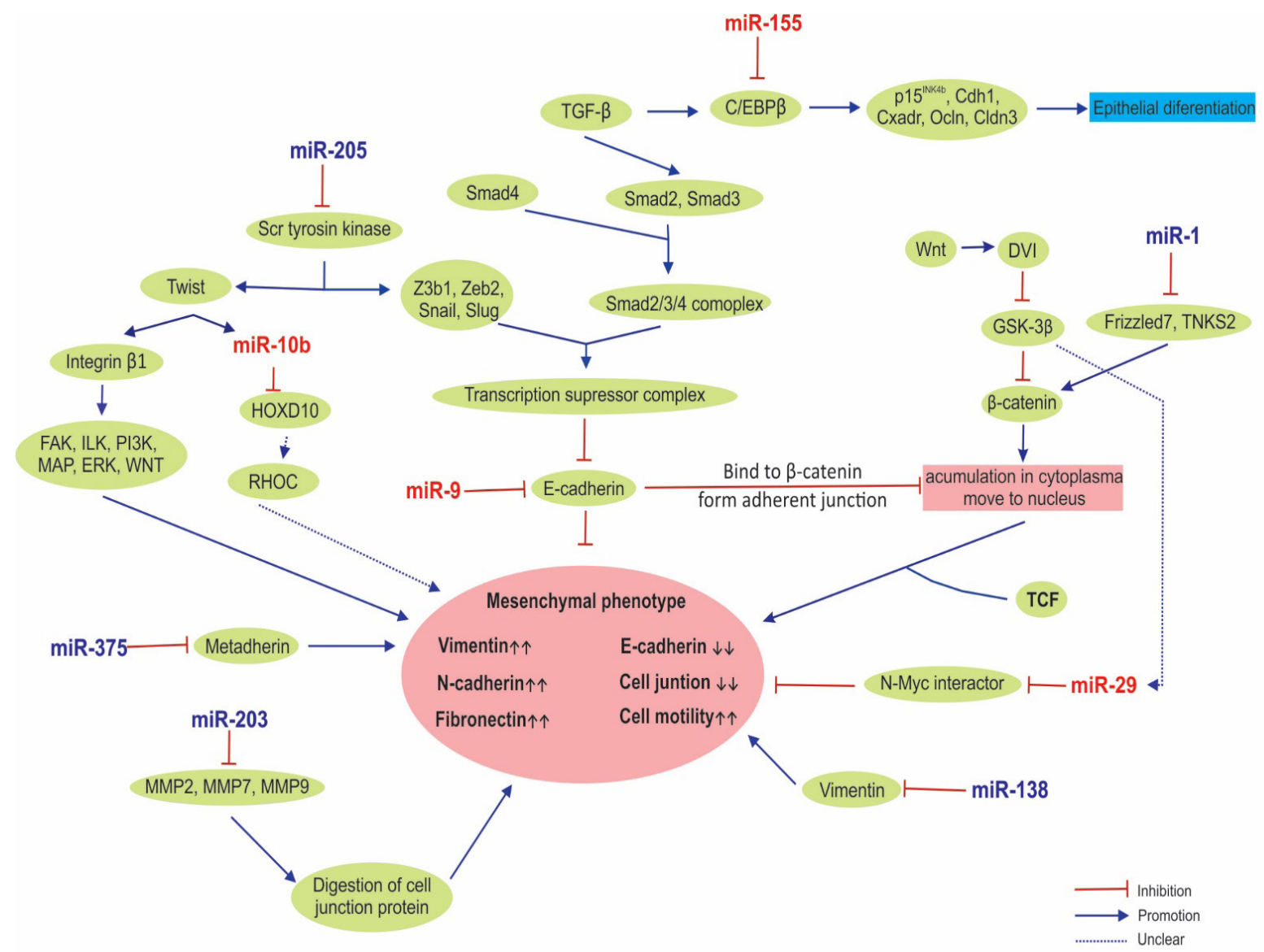

FIGURE 2. The role of several signaling pathways and microRNAs regulate the EMT process.

Using oligonucleotide as an anticancer drug still faces some obstacles. The fact that oligonucleotides are susceptible to degradation by nuclease reduces their stabilityin serum. Recently, the modifications of the oligonucleotide at the backbone particularly on sugar and phosphate groups give resistant properties to enzyme nuclease. Several types of oligonucleotides modification products arelocked nucleic acid (LNA), 2'-fluoro (2'-F), 2'-O-methoxyethyl (2'-O-MOE), 2'-O-methyl (2'-O-Me). Further oligonucleotide modification is necessary to resolve another fact that it could stimulate an immune response by binding to immune receptors such as toll-like receptors and retinoic acidinducible gene 1 . This binding promotes interferon secretion and further immune response. The modifications that reduce or eliminate the side effect of oligonucleotide in immune response without changes in the sequences are established for now. ${ }^{44}$

The delivery system is important when using the oligonucleotide as the drug. Accumulation of this molecule in healthy tissue may cause toxicity in systemic therapy administration. ${ }^{45}$ Direct conjugation is one of the systemic delivery systems use in oligonucleotide therapy to prevent unspecific oligonucleotide tissue accumulation. The oligonucleotide is conjugated to other molecules such as modified galactosamine (GalNAc). This molecule can increase the uptake of the oligonucleotide into the targeted cell by binding to its receptors. Treatment for HCV infection patients with modified galactosamine conjugatedanti microRNA has been enter in trial phase II. ${ }^{44}$ This suggests the treatment in cancer casesusing the same approach is visible. Further, the new approach of 
the delivery system for oligonucleotide therapy has been performed in another study. The Discovery of a nanoparticle 3-ways junction of packaging RNA (pRNA-3WJ) as the systemic delivery system is a novelty approach to overcome unspecific targeting therapy using oligonucleotide. The 3WJ-pRNA can internalize by specific the target cancer cells as therapy in the systemic drug administration. Treatment of antimicroRNA 3WJ-pRMA on the cell line MDA-MB-231 as well as in vivo study using mice TNBC model showed that this new molecule could specifically internalize into cancer cells to suppress the tumor growth. ${ }^{46}$

\section{CONCLUSIONS}

In conclusion, EMT is an important process that contributes to the distant metastatic, and correlate with poor prognosis of breast cancer patients. MicroRNAs possess important roles in EMT regulation through signaling pathways such as TGF- $\beta$, WNT, and Twist. The discovery of systemic delivery such as direct conjugation and nano-particle that could transport oligonucleotides to the targeted site without toxic effect allows developing microRNA targeted therapy approach inhibiting the EMT in breast cancer patients. Therefore, this approach may suppress distant metastasis and improve the survival rate of breast cancer patients.

\section{ACKNOWLEDGEMENT}

No conflict of interest in preparing the manuscript.

\section{REFERENCES}

1. Ferlay J, Soerjomataram I, Dikshit $\mathrm{R}$, Eser S, Mathers C, Rebelo M, et al. Cancer incidence and mortality worldwide: Sources, methods and major patterns in GLOBOCAN 2012. Int J Cancer 2015; 136:E359-86. http://doi.org/10.1002/ijc.29210
2. Lord SJ, Kiely BE, Pearson S-A, Daniels B, O'Connell DL, Beith $\mathrm{J}$, et al. Metastatic breast cancer incidence, site and survival in Australia, 2001-2016: a populationbased health record linkage study protocol. BMJ Open 2019; 9:e026414. h t t p s://d o i.org/10.1136/ bmjopen-2018-026414

3. Wang R, Zhu Y, Liu X, Liao X, He J, Niu L. The Clinicopathological features and survival outcomes of patients with different metastatic sites in stage IV breast cancer. BMC Cancer 2019; 19:1091.

https://doi.org/10.1186/s12885-019-6311-z

4. Singh A, Settleman J. EMT, cancer stem cells and drug resistance: an emerging axis of evil in the war on cancer. Oncogene 2010; 29:4741-51. http://doi.org/10.1038/onc.2010.215

5. Owens TW, Naylor MJ. Breast cancer stem cells. Front Physiol 2013; 4:225. https://doi.org./10.3389/fphys.2013.00225

6. Scioli MG, Storti G, D’Amico F, Gentile P, Fabbri G, Cervelli V, et al. The role of breast cancer stem cells as a prognostic marker and a target to improve the efficacy of breast cancer therapy. Cancers (Basel) 2019; 11:1021.

https://doi.org/10.3390/cancers11071021

7. Konge J, Leteurtre F, Goislard M, Biard D, Morel-Altmeyer S, Vaurijoux $\mathrm{A}$, et al. Breast cancer stem cell-like cells generated during TGF $\beta$-induced EMT are radioresistant. Oncotarget 2018; 9:23519-31.

https://doi.org/10.18632/oncotarget.25240

8. Aktas B, Tewes M, Fehm T, Hauch S, Kimmig R, Kasimir-Bauer S. Stem cell and epithelial-mesenchymal transition markers are frequently overexpressed in circulating tumor cells of metastatic breast cancer patients. Breast Cancer Res 2009; 11(4):R46. https://doi.org/10.1186/bcr2333

9. Zhang J, Tian X, Xing J. Signal transduction pathways of EMT Induced by TGF- $\beta$, SHH, and WNT and their crosstalks. J Clin Med 2016; 5:41. 
https://doi.org/10.3390/jcm5040041

10. Choi J, Sun YP, Joo CK. Transforming growth factor- $\beta 1$ represses E-cadherin production via Slug expression in lens epithelial cells. Investig Ophthalmol Vis Sci 2007; 48:2708-18. https://org.doi/10.1167/iovs.06-0639

11. Bartel DP. MicroRNAs: genomics, biogenesis, mechanism, and function. Cell 2004; 116: 281-97.

https://doi.org/10.1016/S00928674(04)00045-5

12. Tiwari N, Gheldof A, Tatari M, Christofori G. EMT as the ultimate survival mechanism of cancer cells. Semin Cancer Biol 2012; 22:194-207.

h t tp s://d oi.orf/10.1016/j . semcancer.2012.02.013

13. Katz E, Dubois-Marshall S, Sims AH, Gautier P, Caldwell H, Meehan RR, et al.An in vitro model that recapitulates the epithelial to mesenchymal transition (EMT) in human breast cancer. PLoS One 2011; 6:e17083. https://doi.org/10.1371/journal. pone.0017083

14. Shuang ZY, Wu WC, $\mathrm{Xu}$ J, Lin G, Liu YC, Lao XM, et al. Transforming growth factor- $\beta 1$-induced epithelialmesenchymal transition generates ALDH-positive cells with stem cell properties in cholangiocarcinoma. Cancer Lett 2014; 354:320-8.

h t t p s://d oi.org/10.1016/j . canlet.2014.08.030

15. Huang J, Li H, Ren G. Epithelialmesenchymal transition and drug resistance in breast cancer. Int J Oncol 2015; 47:840-8.

https://doi.org/10.3892/ijo.2015.3084

16. Johansson J, Berg T, Kurzejamska E, Pang M, Tabor V, Jansson M, et al. MiR155-mediated loss of C/EBP b shifts the TGF- $b$ response from growth inhibition to epithelial-mesenchymal transition, invasion and metastasis in breast cancer. Oncogene 2013; 32:5614-24.

https://doi.org/10.1038/onc.2013.322

17. Li X, Xu Y, Chen Y, Chen S, Jia X, Sun $\mathrm{T}$, et al. SOX2 promotes tumor metastasis by stimulating epithelial- to-mesenchymal transition via regulation of $\mathrm{WNT} / \beta$-catenin signal network. Cancer Lett 2013; 336:379-89.

18. Shan S, Lv Q, Zhao Y, Liu C, Sun Y, $\mathrm{Xi} \mathrm{K}$, et al. Wnt/ß-catenin pathway is required for epithelial to mesenchymal transition in CXCL12 over expressed breast cancer cells. Int J Clin Exp Pathol 2015; 8:12357-67.

19. Jang G-B, Kim J-Y, Cho S-D, Park K-S, Jung J-Y, Lee $\mathrm{H}-\mathrm{Y}$, et al. Blockade of Wnt/ $\beta$-catenin signaling suppresses breast cancer metastasis by inhibiting CSC-like phenotype. Sci Rep 2015; 5:12465. https://doi.org/10.1038/srep12465

20. Yang J, Hou Y, Zhou M, Wen S, Zhou J, $\mathrm{Xu}$ L, et al. Twist induces epithelialmesenchymal transition and cell motility in breast cancer via ITGB1FAK/ILK signaling axis and its associated downstream network. Int J Biochem Cell Biol 2016; 71:62-71.

h t t p s://d oi.org/10.1016/j. biocel.2015.12.004

21. Glackin CA. Targeting the Twist and Wnt signaling pathways in metastatic breast cancer. Maturitas 2014; 79(1):48-51.

ht tps://doi.org/10.1016/j . maturitas.2014.06.015

22. MacFarlane L-A, Murphy PR. MicroRNA: biogenesis, function and role in cancer. Curr Genomics 2010; 11:537-61.

https://doi.org/10.2174/138920210793175895

23. Nishihara T, Zekri L, Braun JE, Izaurralde E. MiRISC recruits decapping factors to miRNA targets to enhance their degradation. Nucleic Acids Res 2013; 41:8692-705. https://doi.org/10.1093/nar/gkt619

24. Liu T, Hu K, Zhao Z, Chen G, Ou X, Zhang $\mathrm{H}$, et al. MicroRNA-1 down-regulates proliferation and migration of breast cancer stem cells by inhibiting the Wnt/ $\beta$-catenin pathway. Oncotarget 2015; 6:41638-49.

https://doi.org/10.18632/oncotarget.5873

25. Peng J, Yuan $\mathrm{C}$, Wu Z, Wang Y, Yin $\mathrm{W}$, Lin $\mathrm{Y}$, et al. Upregulation of 
microRNA-1 inhibits proliferation and metastasis of breast cancer. Mol Med Rep 2020; 22:454-64.

https://doi.org/10.3892/mmr.2020.11111

26. Zhao S, Han J, Zheng L, Yang Z, Zhao L, Lv Y. MicroRNA-203 regulates growth and metastasis of breast cancer. Cell Physiol Biochem 2015; 37(1):35-42. https://doi.org/10.1159/000430331

27. Mikami S, Katsube KI, Oya M, Ishida M, Kosaka T, Mizuno R, et al. Expression of Snail and Slug in renal cell carcinoma: E-cadherin repressor Snail is associated with cancer invasion and prognosis. Lab Investig 2011; 91(10):1443-58.

https://doi.org/10.1038/labinvest.2011.111

28. Zhao H, Yang Z, Wang X, Zhang X, Wang M, Wang Y, et al. Triptolide inhibits ovarian cancer cell invasion by repression of matrix metalloproteinase 7 and 19 and upregulation of E-cadherin. Exp Mol Med 2012; 44:633-41.

29. Taube JH, Malouf GG, Lu E, Sphyris $\mathrm{N}$, Vijay V, Ramachandran PP, et al. Epigenetic silencing of microRNA-203 is required for EMT and cancer stem cell properties. Sci Rep 2013; 3:2687. https://doi.org/10.1038/srep02687

30. Su CM, Lee WH, Wu ATH, Lin YK, Wang LS, Wu CH, et al. Pterostilbene inhibits triple-negative breast cancer metastasis via inducing microRNA-205 expression and negatively modulates epithelialto-mesenchymal transition. J Nutr Biochem 2015; 26:675-85.

h t tps://doi.org/10.1016/j . jnutbio.2015.01.005

31. Xiao, Humphries, Yang, Wang. MiR205 Dysregulations in breast cancer: the complexity and opportunities. noncoding RNA2019; 5(4):53. https://doi.org/10.3390/ncrna5040053

32. Liu Y, Zhao J, Zhang P-Y, Zhang Y, Sun S-Y, Yu S-Y, et al. MicroRNA-10b targets E-cadherin and modulates breast cancer metastasis. Med Sci Monit 2012; 18:BR299-308.

https://doi.org/10.12659/msm.883262

33. Ma L, Teruya-Feldstein J, Weinberg
RA. Tumour invasion and metastasis initiated by microRNA-10b in breast cancer. Nature 2007; 449(7163):682-8. https://doi.org/10.1038/nature06174

34. Rostas JW III, Pruitt HC, Metge BJ, Mitra A, Bailey SK, Bae S, et al. microRNA-29 negatively regulates EMT regulator $\mathrm{N}$-myc interactor in breast cancer. Mol Cancer 2014; 13:200.

https://doi.org/10.1186/1476-4598-13-200

35. Devine DJ, Rostas JW, Metge BJ, Das S, Mulekar MS, Tucker JA, et al. Loss of N-Myc interactor promotes epithelial-mesenchymal transition by activation of TGF- $\beta /$ SMAD signaling. Oncogene 2014; 33(20):2620-8. https://doi.org/10.1038/onc.2013.215

36. Wu Y, Shi W, Tang T, Wang Y, Yin X, Chen Y, et al. miR-29a contributes to breast cancer cells epithelialmesenchymal transition, migration, and invasion via down-regulating histone H4K20 trimethylation through directly targeting SUV420H2. Cell Death Dis 2019; 10:176. https://doi.org/10.1038/s41419-019-1437-0

37. Zhang J, Liu D, Feng Z, Mao J, Zhang C, Lu Y, et al. MicroRNA-138 modulates metastasis and EMT in breast cancer cells by targeting vimentin. Biomed Pharmacother 2016; 77:135-41.

h t tps://d oi.org/10.1016/j . biopha.2015.12.018

38. Zhao C, Ling X, Li X, Hou X, Zhao D. MicroRNA-138-5p inhibits cell migration, invasion and EMT in breast cancer by directly targeting RHBDD1. Breast Cancer 2019; 26(6):817-25. https://doi.org/10.1007/s12282-01900989-w

39. Ward A, Balwierz A, Zhang JD, Küblbeck M, Pawitan Y, Hielscher T, et al. Re-expression of microRNA-375 reverses both tamoxifen resistance and accompanying EMT-like properties in breast cancer. Oncogene 2013; 32:1173-82.

https://doi.org/10.1038/onc.2012.128

40. Li X, Kong X, Huo Q, Guo H, Yan S, Yuan $\mathrm{C}$, et al. Metadherin enhances the invasiveness of breast cancer 
cells by inducing epithelial to mesenchymal transition. Cancer Sci 2011; 102(6):1151-7.

https://doi.org/10.1111/j.13497006.2011.01919.x

41. Yu DD, Lv MM, Chen WX, Zhong SL, Zhang XH, Chen L, et al. Role of miR-155 in drug resistance of breast cancer. Tumor Biol 2015; 36(3):1395-401. https://doi.org/10.1007/s13277-015-3263-z

42. Almeida MI, Reis RM, Calin GA. MYCmicroRNA-9-metastasis connection in breast cancer. Cell Res 2010; 20:603-4.

https://doi.org/10.1038/cr.2010.70

43. Si ML, Zhu S, Wu H, Lu Z, Wu F, Mo YY. miR-21-mediated tumor growth. Oncogene 2007; 26:2799-803.

https://doi.org/10.1038/sj.onc.1210083
44. Gibson NW. Clinical engineered microRNA therapeutics. JR Coll Physician Edinb 2014; 44(3):196-200. https://doi.org/10.4997/JRCPF.2014.302

45. Lennox KA, Owczarzy R, Thomas DM, Walder JA, Behlke MA. Improved performance of anti-miRNA oligonucleotides using a novel non-nucleotide modifier. Mol Ther Nucleic Acids 2013; 2:e117.

https://doi.org/10.1038/mtna.2013.46

46. Shu D, Li H, Shu Y, Xiong G, Carson WE, Haque F, et al.Systemic delivery of anti-miRNA for suppression of triple negative breast cancer utilizing RNA nanotechnology. ACS Nano2015; 9:9731-40.

https://doi.org/10.1021/acsnano.5b02471 